Full length article

\title{
Prediction of urban residential end-use water demands by integrating known and unknown water demand drivers at multiple scales I: Model development
}

\author{
K. Rathnayaka ${ }^{\mathrm{a}, *}$, H. Malano ${ }^{\mathrm{a}}$, M. Arora ${ }^{\mathrm{a}}$, B. George ${ }^{\mathrm{b}}$, S. Maheepala ${ }^{\mathrm{c}}$, B. Nawarathna ${ }^{\mathrm{d}}$ \\ a Department of Infrastructure Engineering, The University of Melbourne, Parkville, VIC 3010, Australia \\ ${ }^{\mathrm{b}}$ Integrated Water and Land Management Program, ICARDA, Cairo, Egypt \\ c City West Water Corporation, Footscray, Victoria 3011, Australia \\ d Urban Water Balance Unit, Bureau of Meteorology, VIC 3001, Australia
}

\section{A R T I C L E I N F O}

\section{Article history:}

Received 20 April 2016

Received in revised form

17 November 2016

Accepted 17 November 2016

Available online 24 November 2016

\section{Keywords:}

End-use water demand

Residential water use

Stochastic modeling

Spatial variability

Temporal variability

\begin{abstract}
A B S T R A C T
Detailed prediction of water demand by their end-uses at multiple scales is essential to support planning of Integrated Urban Water Management, an increasingly applied approach to deal with the problem of water scarcity. This paper presents an urban residential water demand modeling framework that can predict end-use water demand at multiple scales, especially at small scales with a robust explanatory capacity. This is achieved by integrating the complex water demand dynamics of urban residential water use and their underlying variables into a single model. The model described in this study can predict shower, toilet, tap, dishwasher, clothes washer, irrigation, evaporative cooler, bath, and other uses which account for the entire household water use. The model aims to predict water demand at multiple spatial (household/cluster/suburb) and temporal scales (hourly, daily, weekly and seasonal) by considering behavioral differences triggered by factors such as seasonality and presence of people at home. The model incorporates an improved representation of spatial variability by considering behavioral differences between customer groups, and improves the capability to deal with areas with different demographic and housing characteristics. This research confirms the capacity of stochastic modeling methods to represent unexplained behavior of water consumers.
\end{abstract}

(c) 2016 Elsevier B.V. All rights reserved.

\section{Introduction}

Population growth combined with increased economic activity, improving living standards, urbanization, and uncertainty due to climate change cause water scarcity in different parts of the world (Domene and Sauri, 2006; House-Peters et al., 2010; Kenney et al., 2008; Lee et al., 2012; Haddeland et al., 2014). These factors together with prolonged and severe drought from 2002 to 2008 in South Eastern Australia have increased the pressure on Australian cities to act on guaranteeing water security for the future. Among a number of other water supply augmentation projects and demand management programs, the popularity of Integrated Urban Water

\footnotetext{
* Corresponding author.

E-mail addresses: krathnayaka@unimelb.edu.au, rpkcs78@gmail.com (K. Rathnayaka), h.malano@unimelb.edu.au (H. Malano), marora@unimelb.edu.au (M. Arora),B.George@cgiar.org (B. George), Shiroma.Maheepala@citywestwater.com.au (S. Maheepala), B.Nawarathna@bom.gov.au (B. Nawarathna).
}

Management (IUWM) as an approach to obtaining sustainable solutions to deal with this problem has increased.

One key feature of the IUWM is that it seeks to address water scarcity through diversification of water sources (Maheepala et al., 2010). This enables matching water demands with specific quality requirements to sources of appropriate quality and quantity (i.e. supply water to fit-for-purpose). These water sources include grey water, roof top water, recycled water, stormwater, surface water, groundwater and desalinated water at different spatial scales. Some of these alternative sources such as recycled water are available at larger spatial scales (e.g. city scale). Some other alternative supplies such as roof top water, grey water and stormwater can be available at both household and precinct scales. These sources, which are comparatively small in quantity of water, may be adequate for one or a small number of households, and their availability is variable even at sub-daily scale. Therefore, the optimal use of water available in decentralized systems requires a detailed understanding of water demand by various end-uses at different spatial scales 
(i.e. household, precinct, suburb and city) and temporal scales (i.e. sub-daily to annual).

\section{Water demand modeling}

The focus of early water demand models such as simple econometric and time series models is rather too narrow to develop accurate forecasting methods to improve the management of water supply infrastructure and reduce the risks borne by water suppliers (Baumann et al., 1998). In general, these models produce demand outputs at monthly or annual scale for the whole of an urban water system.

With the introduction of the IUWM concept, the expected role of water demand forecasting and simulation models has changed dramatically. Mitchell et al. (2007) identified it as a significant change in the modeling approach and describes the change as moving away from spatially lumped approaches and assumptions about linearity of systems processes and responses. IUWM has driven water demand modeling at an end-use scale and at small spatial and temporal scales, something that is not fully achievable through spatially lumped demand prediction models. With this emerging need fostered by IUWM, total water cycle models that integrate water supply, demand, and wastewater were developed to incorporate the required level of granularity. Although these models serve as important tools, spatial lumping is a common limitation (e.g. Aqua cycle (Mitchell et al., 2001) and Watercress (Clark and Cresswell, 2007)).

Rathnayaka et al. (2011) reviewed the available end-use water demand models and identified the limitations present in end-use models to accommodate numerous variables affecting urban residential water demand to date. In particular, the review focuses on the limited capacity of existing end-use water demand models to consider the impact of multiple variables affecting the behavior of a predictor variable such as frequency of a water end-use. Further, these end-use models have limited capacity to represent both spatial and temporal variability. Rathnayaka et al. (2011) describe these limitations in detail.

The complexity of urban water systems arises from the constant changes due to demographics, urban renewal, technology uptake rates and changing water policies (Mitchell et al., 2007). These complexities make it necessary to understand and incorporate the behavior of water demand in response to these spatial and temporal system changes. Mitchell et al. (2007) emphasize the difficulty in capturing the complexity of urban residential water system processes in a simple deterministic representation.

The ability of a water demand prediction model to consider all reasonable variables is important for several reasons. Firstly, it must represent spatial and temporal variability and produce multiple water demand outputs. It must also have a sound explanatory power for the model outputs and must be suitable for scenario planning. Additionally, it must maintain the validity of the model over time by validating the behavior of key variables and revising the model processes designed to describe the temporal system changes.

Although integrating diverse socio-economic and environmental variables into a single conventional model remains difficult (Galán et al., 2009), data availability and computational power, which are often identified as limitations, have improved substantially in the recent past (Liu et al., 2015). Such an increase in data richness has led to progress in identifying and quantifying relationships among numerous social, weather, and water consumption variables. Nevertheless, methodologies are still lacking that have the ability to incorporate these types of data and to take advantage of this rich data availability to explain demand relationships at multiple scales (House-Peters and Chang, 2011).
This paper presents an improved end-use water demand prediction modeling method developed to deliver the capabilities described in the foregoing discussion. The model uses several techniques that are described in Section 4 to achieve these capabilities. The model was developed using a comprehensive set of data collected mainly by water utilities in Melbourne, Australia during 2005 to 2012, which are detailed in Section 3. Section 4 explains the model structure in detail and Section 5 explains the sensitivity analysis of the key variables used in the model. The application of the model to water end-uses is discussed in the companion paper Rathnayaka et al. (forthcoming) with the validation of the model at different temporal scales.

\section{Data}

A broad set of fine scale data collected mainly by two water utilities in Melbourne, Australia - Yarra Valley Water (YVW) and City West Water (CWW) are used in this study. Data samples and their use in this study are given in Table 1.

This data availability enhanced the data driven approach of the model and minimized the assumptions involved in the model.

\section{The modeling framework}

\subsection{The concept}

Consumer is the main driver of urban residential water demand. Their water consumption behavior is significantly different from one another (Roberts, 2005b; Willis et al., 2009). Winter water consumption between users is significantly variable and winter water use is assumed to be the base water use with no weather, policy or other external forcing. The causes behind this variability are associated with the users themselves. These factors include demographic, socio-economic and physical factors. Notably, these factors vary spatially and some of them show observable trends over time. In addition, external factors that vary in space and time also alter user behavior. The changing user behaviors can be observed in response to weather or to water restrictions: in particular, in end-uses such as garden irrigation and evaporative cooling.

In addition to these external factors, users themselves can affect each other's behavior. This can be due to communication between them such as disseminating a message about water saving technologies, which may in turn be triggered by an awareness program. These interactions are not modeled in this study considering the limitation in available data, their potentially minor significance and the softness of these interactions, all of which make them highly uncertain to be captured by a model while maintaining the accuracy of the outputs and restricting the model's complexity.

This paper proposes a modeling approach that consists of two main components: user groups and end-use models to represent the diverse components and variability in the urban residential water use. The study identifies groups of households with common characteristics related to their water usage herein called "user groups". User groups consider the variability of consumers related to their water usage, while end-use models consider the effect of external factors such as temperature on water use. Sections 4.3 and 4.4 describe these key components of the model. Scales and the structure of the model are described in Section 4.2.

\subsection{Output scales and structure of the model}

The model is intended to predict total water demand and enduse water demands from household to larger spatial scales (Fig. 1). The model is also intended to predict water demand and end-use 
Table 1

Data characteristics and use.

\begin{tabular}{|c|c|c|}
\hline Data sample & Characteristics & Use \\
\hline $\begin{array}{l}\text { 2010/12 Residential End-Use Measurement } \\
\text { program (REUM) conducted by YVW and CWW } \\
\text { and their survey data (Roberts et al., 2011) }\end{array}$ & $\begin{array}{l}\text { Measured water use data at five seconds interval } \\
\text { from } 100 \text { households each for two weeks period in } \\
\text { winter } 2010 \text { and summer } 2012 \text { that were } \\
\text { disaggregated into individual end-use events. } \\
\text { Survey data on household characteristics }\end{array}$ & $\begin{array}{l}\text { Development of the end-use models including } \\
\text { identification of probability distributions. } \\
\text { Temporal analysis of residential water end-uses }\end{array}$ \\
\hline $\begin{array}{l}\text { 2010/12 household water usage data at hourly } \\
\text { scale by YVW REUM program }\end{array}$ & $\begin{array}{l}\text { Data are available from } 100 \text { households for the } \\
\text { period October } 2010 \text { to April } 2012\end{array}$ & $\begin{array}{l}\text { Model development-hourly scale (Winter 2011, } \\
\text { Summer 2012) and model validation at hourly } \\
\text { scale (summer 2011) }\end{array}$ \\
\hline $\begin{array}{l}\text { Evaporative cooler water use data collected by } \\
\text { YVW (Roberts, 2005a) }\end{array}$ & $\begin{array}{l}\text { Data available for six weeks from late January to } \\
\text { mid-March } 2005 \text { from } 11 \text { homes with evaporative } \\
\text { air conditioners }\end{array}$ & $\begin{array}{l}\text { Data analysis-Evaporative cooler water demand } \\
\text { model. }\end{array}$ \\
\hline $\begin{array}{l}2011 \text { YVW “Appliance stock and usage } \\
\text { behavior/patterns surveys” (ASUPS) and } \\
\text { quarterly billing records of those households } \\
\text { (Roberts, 2012) }\end{array}$ & $\begin{array}{l}\text { Survey data and billing records from } 1131 \\
\text { households for year } 2011 \text {. Data on family } \\
\text { composition, dwelling characteristics, household } \\
\text { appliances, their efficiency, and water use patterns }\end{array}$ & $\begin{array}{l}\text { Identification of attributes of user groups. } \\
\text { Model validation at quarterly scale }\end{array}$ \\
\hline $\begin{array}{l}\text { Meter readings of YVW households of which } \\
\text { end-use data was obtained, for } 2009 \text { to } 2012\end{array}$ & $\begin{array}{l}\text { Data at each quarter of the year at household scale } \\
\text { from } 100 \text { households }\end{array}$ & Model validation at quarterly scale \\
\hline Weather data (Bureau of Meteorology, 2011) & $\begin{array}{l}\text { Past records of daily rainfall and temperature are } \\
\text { available for all weather stations in Melbourne }\end{array}$ & $\begin{array}{l}\text { Development of irrigation and evaporative cooler } \\
\text { water demand models }\end{array}$ \\
\hline $\begin{array}{l}\text { Census data on demographics and housing } \\
\text { (Australian Bureau of Statistics, 2006) }\end{array}$ & $\begin{array}{l}\text { Data on household size, age composition and } \\
\text { dwelling type are available at each statistical area }\end{array}$ & $\begin{array}{l}\text { Identification of user groups those are prominent } \\
\text { in Melbourne }\end{array}$ \\
\hline
\end{tabular}

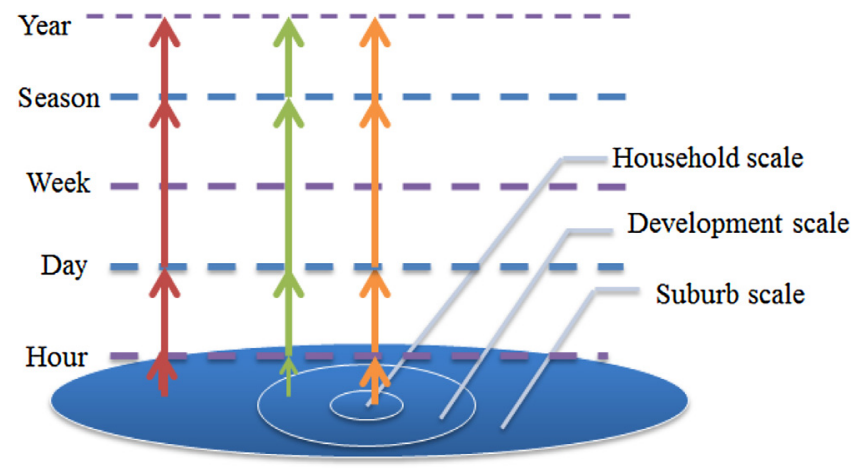

Fig. 1. Output scales of the model.

water demand at temporal scales ranging from hourly to annual scales (Fig. 1).

Fig. 2 shows the structure and factors considered in each step of the model spatial integration. Rathnayaka et al. (2014) studied the factors affecting the urban residential water use and identified household size, typology of dwelling, presence of children under 12 years of age, presence of water use appliances/end-uses and appliance efficiency, presence and size of garden, and garden irrigation equipment as the statistically significant factors that explain the variability of household water use.

As shown in Fig. 2, water demand from all household end-uses is aggregated to obtain the total household water demand. The aggregated water demand of a number of households in a user group results in the water demand of that user group, and the aggregated water demand of all user groups represents the total water demand. The household scale is used as the smallest spatial scale in preference to a per-person scale since data is available at a household scale. A per-person analysis would require disaggregation of the primary data and this rescaling will not reconcile the different scales (Makki et al., 2015). Furthermore, a greater number of key variables (e.g. availability of end-uses/appliances, their efficiency, dwelling type) are involved at the household scale (Rathnayaka et al., 2014; Makki et al., 2015).

The daily time scale is used as the operational temporal scale since it does not involve disaggregation or aggregation of the primary data. The model can also predict demand at hourly, weekly and seasonal scales considering the variability of water use at different temporal scales. This variability is determined by various factors. Rathnayaka et al. (2015) studied the temporal variability of water end-uses at seasonal scales and found that shower and irrigation water uses show statistically significant difference between summer and winter. The same authors also found that daily variations in irrigation and evaporative cooler end-use are shown to be weather sensitive (Rathnayaka et al., 2015). A further analysis of water end-uses for their difference between weekdays and weekends found that water use of clothes washer is significantly different between weekdays and weekends (please see Appendix A). Further, users exhibit daily routines in water use that may respond to their work arrangements, age and other behavioral factors. The composite result of these daily individual water use patterns at household scale has been observed in studies of enduse measurements (Roberts et al., 2011; Athuraliya et al., 2012). This composite temporal pattern is applied in this study to explain water demand at an hourly scale. Fig. 3 illustrates the main temporal scales within a year and causative factors for each scale.

\subsection{User groups (UG)}

"User groups" is the concept used in this model to improve the representation of the variability of household water use, to enable the application of the model outside of its validated data range, and to improve its explanatory capacity. Fig. 4 illustrates the key components of the overall model and their links.

The key explanatory variables household size, dwelling typology and presence of children under 12 years are organized in a hierarchical order according to their degree of correlation with household water use with the aim of classifying households into user groups as shown in Fig. 4 (Rathnayaka et al., 2014). These key household characteristics are also used as input variables for the model and are used to identify user groups of households to be modeled since these data are available publicly at each statistical area (Department of Planning and Community Development, 2011; Australian Bureau of Statistics, 2006). Therefore, each household can be modeled individually using a relevant user group. Theoretically, the classification results in 48 user groups ( 8 household sizes $\times 3$ dwelling types $\times 2$ categories of presence of children). However, 25 user groups were excluded from the model due to infeasible combinations such as household size 1 with children or insignificant overall volume of water use by some user groups. A further reduction in the number of user groups was achieved by combining user groups that show similar water use behavior (i.e. 


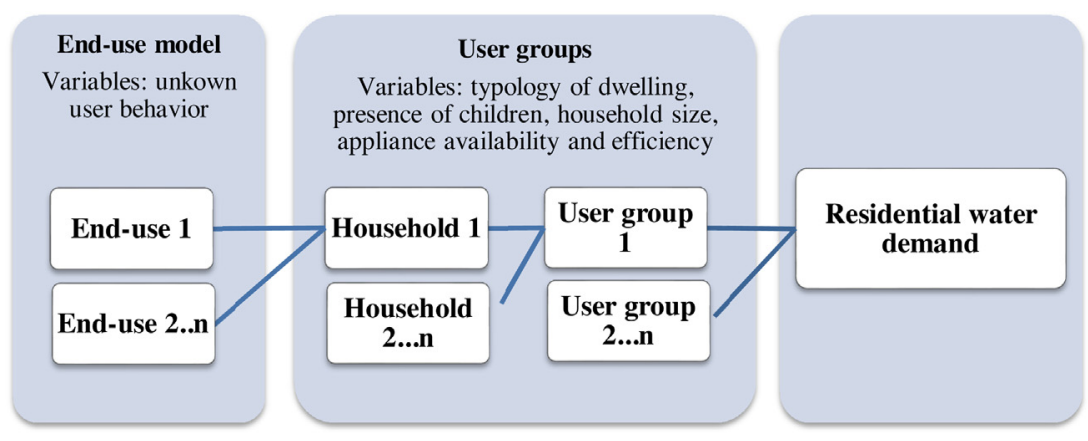

Fig. 2. Model spatial scale representation.

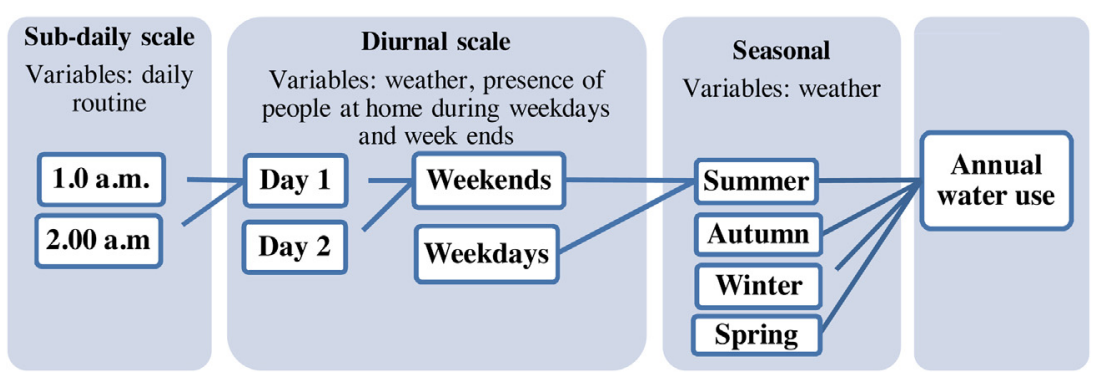

Fig. 3. Model temporal scale representation.

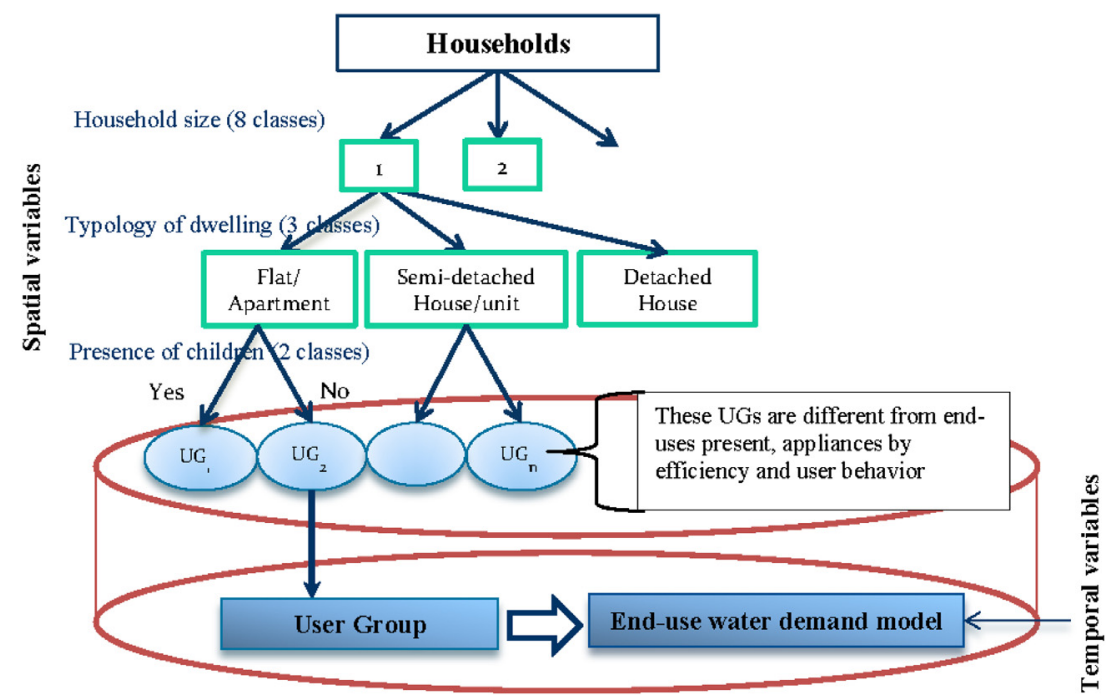

Fig. 4. The overall modeling framework.

user groups of household size 6 with and without children). The user groups selected for the model are displayed in Table 2. While households those do not fit these selected user groups are negligible, these households can be modelled using user groups with similar household sizes.

User groups exhibit different penetration rates for water use appliances, end-uses and efficient appliances, and different water consumption behaviors. The penetration rates of water end-uses and efficient water use appliances for different user groups were identified using the 2011 ASUP survey dataset consisting of 1131 household data. It was found that almost all households have a shower, tap, toilet, and clothes washer. Most of the households have a bath but only $47 \%$ of YVW households use the bath while for CWW, this percentage is $53 \%$. Therefore, the bath water demand model is applied only to half of the households (50\%) in each user group. The presence of a dishwasher is less frequent in multi-storey dwellings with small families and varies from $47 \%$ to $87 \%$ among user groups. The presence of an evaporative cooler varies from $11 \%$ to $37 \%$ and the presence of a garden varies from $42 \%$ to $93 \%$ among user groups. The presence of dual flush toilets ranges from $81 \%$ to $100 \%$ and the presence of front loader washing machine varies from $31 \%$ to $79 \%$. These penetration rates are considered in modeling water end-uses at each user group as discussed in the next section.

The user group concept allows the model to consider the effect of a number of key variables described above. However, the ability of these variables to explain the spatial variability in household water use is rather moderate $\left(R^{2} \approx 40 \%\right.$ ) (Rathnayaka et al., 2014). The residual unknown variability which is rather considerable can be due to all other unexplained factors such as culture, attitudes to water use and education (Rathnayaka et al., 2014). This unknown variability within each user group is taken into account by using a stochastic end-use model for each user group. Therefore, each user 
Table 2

The user groups and their basic characteristics.

\begin{tabular}{|c|c|}
\hline User group & Description \\
\hline 1 & Household size 1, Flat/Apartment, No children under 12 years \\
\hline 2 & $\begin{array}{l}\text { Household size } 1 \text {, Unit/Semi-detached house, No children } \\
\text { under } 12 \text { years }\end{array}$ \\
\hline 3 & Household size 1, Detached house, No children under 12 years \\
\hline 4 & Household size 2, Flat/Apartment with children under 12 years \\
\hline 5 & Household size 2, Flat/Apartment, No children under 12 years \\
\hline 6 & $\begin{array}{l}\text { Household size } 2 \text {, Unit/Semi-detached house with children } \\
\text { under } 12 \text { years }\end{array}$ \\
\hline 7 & $\begin{array}{l}\text { Household size 2, Unit/Semi-detached house, No children } \\
\text { under } 12 \text { years }\end{array}$ \\
\hline 8 & Household size 2, Detached house with children under 12 years \\
\hline 9 & Household size 2, Detached house, No children under 12 years \\
\hline 10 & Household size 3, Flat/Apartment with children under 12 years \\
\hline 11 & Household size 3, Flat/Apartment, No children under 12 years \\
\hline 12 & $\begin{array}{l}\text { Household size } 3 \text {, Unit/Semi-detached house with children } \\
\text { under } 12 \text { years }\end{array}$ \\
\hline 13 & $\begin{array}{l}\text { Household size 3, Unit/Semi-detached house, No children } \\
\text { under } 12 \text { years }\end{array}$ \\
\hline 14 & Household size 3, Detached house with children under 12 years \\
\hline 15 & Household size 3, Detached house, No children under 12 years \\
\hline 16 & $\begin{array}{l}\text { Household size } 4 \text {, Unit/Semi-detached house with children } \\
\text { under } 12 \text { years }\end{array}$ \\
\hline 17 & $\begin{array}{l}\text { Household size } 4 \text {, Unit/Semi-detached house, No children } \\
\text { under } 12 \text { years }\end{array}$ \\
\hline 18 & Household size 4, Detached house with children under 12 years \\
\hline 19 & Household size 4, Detached house, No children under 12 years \\
\hline 20 & Household size 5, Detached house with children under 12 years \\
\hline 21 & Household size 5, Detached house, No children under 12 years \\
\hline 22 & $\begin{array}{l}\text { Household size } 6 \text {, Detached house with or without children } \\
\text { under } 12 \text { years }\end{array}$ \\
\hline 23 & $\begin{array}{l}\text { Household size } 7 \text {, Detached house with or without children } \\
\text { under } 12 \text { years }\end{array}$ \\
\hline
\end{tabular}

group has a unique end-use model considering their behavioral differences among and between them. These unique end-use models improve the explanatory capacity of the model by facilitating the comparison of water demand between user groups and explaining the variability in terms of probabilistic uncertainty.

\subsection{Stochastic end-use model}

The end-use model presented herein can predict shower, toilet, tap, dishwasher, clothes washer, irrigation, evaporative cooler, bath, and other end-uses which enable accounting for the total household water use. This model fulfills three purposes:

- It predicts the water demand of user groups at end-use level,

- It captures the variability within each user group, and;

- It predicts the household water demands at hourly, daily, weekly and seasonal scales.

Daily household water demand is calculated based on each user group to which these households belong. Eq. (1) describes the basic relationship that the model uses to calculate daily household water demand (L/hh/d):

$W D_{h d}=\frac{\sum_{i=1}^{n} E U_{u i}}{N}$

where $\mathrm{WD}_{\mathrm{hd}}$ is the daily household water demand, $\mathrm{N}$ is the number of households of a user group to which these households belong, and $\mathrm{EU}_{\mathrm{ui}}$ is the end-use water demand of the user group for end-use $i$ to $n$ number of end-uses (L/UG/d).The model considers clothes washer, dishwasher, garden irrigation, evaporative cooler, tap, shower, toilet flushing and bath end-uses individually. The "Other" water end-use category represents the residual water use (e.g. leakage, carwash). Due to the limited data availability and its relatively small magnitude, the "Other" water end-use is esti- mated as an average value per user group from the 2010/12 REUM dataset.

End-use water demand of a user group $\left(\mathrm{EU}_{\mathrm{ui}}\right)$ is predicted by considering whether an end-use is present and its volume of water demand. The number of households for which a specific end-use is present is obtained by multiplying the number of households $(\mathrm{N})$ in the user group with the associated Penetration Rate (PR) for that end-use in the user group. This generic relationship is used to calculate daily end-use water demand for a user group $\left(\mathrm{EU}_{\mathrm{ui}}\right)$ as shown in Eq. (2):

$E U_{u i}=(N \times P R \%) \times(F r \times G \times D u r)$

The term "Fr" represents frequency (events/hh/day), "Dur" represents duration of event (minutes) and " $G$ " represents flow rate of event $(\mathrm{L} / \mathrm{min})$. Otherwise volume of water demand is calculated from "frequency" and "volume per event" depending on the specific end-use. Occurrence of use rather than frequency is used in the water demand modeling of bath, dishwasher, clothes washer, evaporative cooler and irrigation to avoid the measurement error arising from recording all discontinuous events as separate events in the measurement program (Roberts et al., 2011). The sum of daily water use is used instead of water use per event to align with the occurrence per day as predictor variable in the end-use models. The predictor variables used by each end-use model are given in Table 3. Detailed description of these models can be found in the companion paper Rathnayaka et al. (forthcoming).

For end-uses present in all households (i.e. shower, toilet and clothes washer), Eq. (2) takes on a slightly different form. For example, shower water demand is calculated considering the two shower efficiency standards that affect its "flow rate". They are efficient showers (flow rate smaller than $15 \mathrm{~L} / \mathrm{min}$ ) and Standard showers (flow rate greater than $15 \mathrm{~L} / \mathrm{min}$ ). In this case, the number of households in a user group (N) is scaled by the percentage of households with efficient showers $\left(P R_{E}\right)$ to calculate the number of households with this type of showers. This amount is then multiplied by the volume of shower use per household which is in turn calculated from the "flow rate" representing efficient showers $\left(G_{E}\right)$, frequency $(\mathrm{Fr})$ and duration (Dur) variables to obtain the shower water demand of households with efficient showers (Eq. (3)):

$E U_{S E}=\left(\left(N \times P R_{E}\right) \times\left(F r \times G_{E} \times D u r\right)\right)$

The shower water demand ( $\mathrm{EU}_{\mathrm{SE}}$ ) predicted by Eq. (3) is combined with the volume of shower water demand predicted for rest of the households with standard showers $\left(\mathrm{EU}_{\mathrm{SS}}\right)$ to predict the total shower water demand for households in the user group using Eq. (4):

$E U_{S S}=\left(\left(N-\left(N \times P R_{E}\right)\right) \times\left(F r \times G_{S} \times D u r\right)\right.$

where $G_{S}$ is the flow rate of standard showers.

The end-use model is based on probability distributions for all predictor variables as a method of capturing the variability of the predictor variables. The values for predictor variables are generated randomly using identified probability distributions based on the observed REUM data. The best probability distribution is chosen out of 56 probability distribution function models to describe each probability space based on a combined selection criteria that includes: the Anderson-Darling (A-D) test (Yap and Sim, 2011), histograms of observed data and probability distributions, ability of probability distributions to provide non-negative values, and ability to provide binary values (applicable for occurrence variables only). To obtain the distribution of end-use water demands, over 10,000 values are generated using Monte-Carlo method for each predictor variable, that ensure an average value representative of the population. Random values for the frequency variable are generated first using the identified probability distribution. If the value 
Table 3

Predictor variables used in end-use models.

\begin{tabular}{|c|c|}
\hline End-use model & Predictor variables \\
\hline Shower water demand model & Penetration rate of efficient showers, Frequency of use, Duration of an event, Flow rate \\
\hline Toilet water demand model & Penetration rate of dual flush toilet, Frequency of use, Volume of an event \\
\hline Tap water demand model & Frequency of use, Volume of an event \\
\hline Bath water demand model & Penetration rate of bath and\% of households use it, Daily occurrence of the event, Daily water use volume \\
\hline Dishwasher water demand model & Penetration rate of dishwasher, Daily occurrence of the event, Daily water use volume \\
\hline Clothes washer water demand model & Penetration rate of front loader clothes washer, Daily occurrence of the event, Daily water use volume \\
\hline Garden irrigation water demand model & Penetration rate of garden, Daily occurrence of the event, Daily water use duration, Flow rate \\
\hline Evaporative cooler water demand model & Penetration rate of evaporative cooler, Daily occurrence of the event, Daily water use volume \\
\hline
\end{tabular}

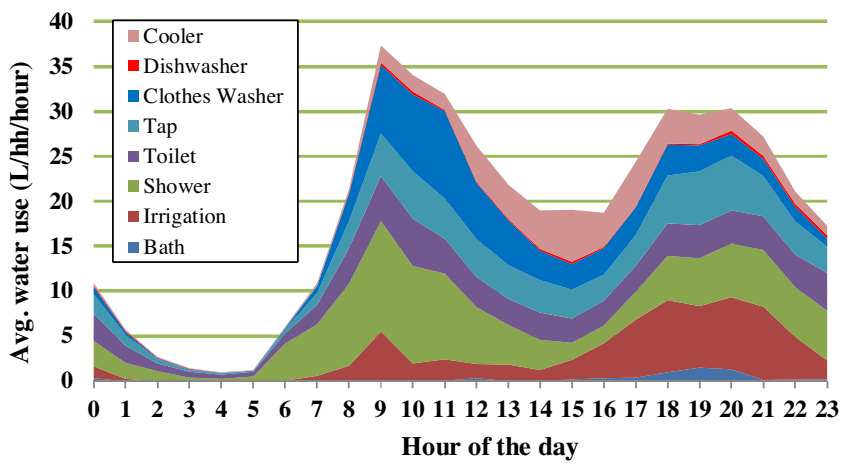

Fig. 5. Hourly water usage patterns for end-uses in summer (Athuraliya et al., 2012).

is greater than zero then random numbers are generated for the duration and flowrate variables from the identified probability distributions. The values of predictor variables are multiplied with each other to predict volume of end-use water demand, assuming those predictor variables are independent or do not shows cross correlation.

The temporal variability of residential water use is observed at hourly, daily, weekly, seasonal and annual scales. Prediction of hourly water demand is necessary for planning of decentralised water supply and wastewater systems (Maheepala et al., 2012; Mirza et al., 2013; Dugge et al., 2012). To predict end-use water demand at an hourly scale $\left(\mathrm{EU}_{\mathrm{h}}\right)$, the daily end-use water demand $\left(E U_{i}\right)$ is multiplied by the probability of occurrence (PO) of that end-use at each hour as shown in Eq. (5). The PO represents the behavioral pattern of users within a day or the hourly water demand dynamics, as follows:

$E U_{h k i}=P O_{k i} \times E U_{i}$

where $\mathrm{EU}_{\mathrm{hki}}$ is the hourly end-use water demand for hour $(\mathrm{k})$ and end-use (i) $(\mathrm{L} / \mathrm{h}), \mathrm{PO}_{\mathrm{ki}}$ is the probability of occurrence for hour $(\mathrm{k})$ and end-use (i), and $\mathrm{EU}_{\mathrm{i}}$ is the daily end-use water demand for enduse (i) (L/d). The probability of occurrence is derived from diurnal patterns of each end-use identified by YVW for summer and winter based on data measured at five seconds intervals. Graphical representations for these diurnal patterns are shown in Figs. 5 and 6 (Roberts et al., 2011; Athuraliya et al., 2012).

Section 4.2 discussed the end-uses that vary from summer to winter, and weekdays to weekends. In these instances, specific probability distributions are applied for predictor variables to describe these different water use behaviors for different time periods.

The variability of daily water demand was also studied for weather sensitive water end-uses. The prediction of evaporative cooler and garden irrigation water demand requires the application of alternative temperature-determined stochastic models to describe water use behaviors triggered by temperature and these models are described in the companion paper (Rathnayaka et al., forthcoming).

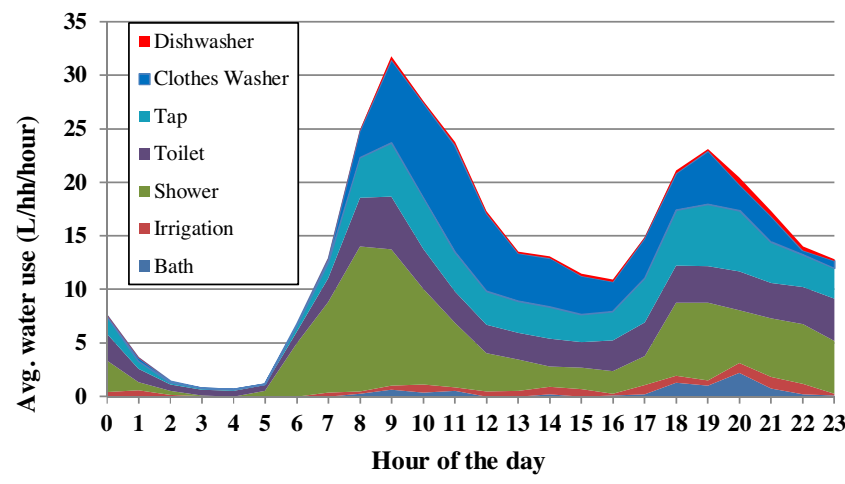

Fig. 6. Hourly water usage patterns for end-uses in winter (Roberts et al., 2011).

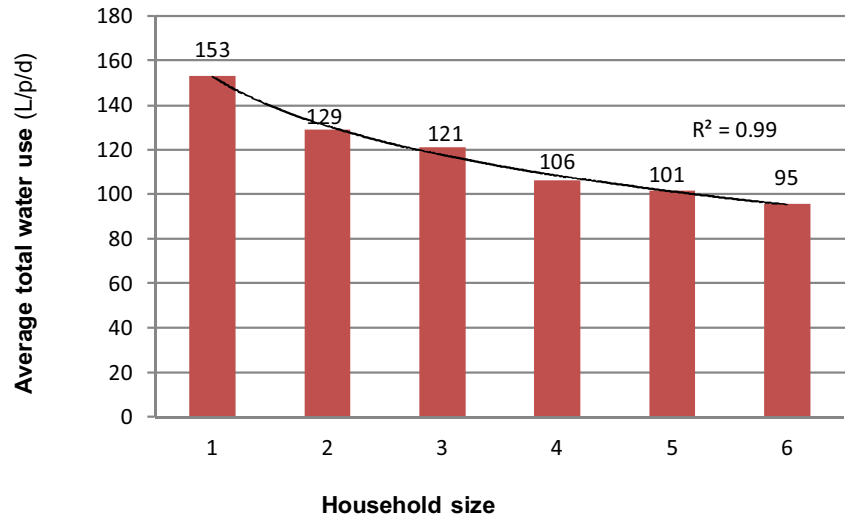

Fig. 7. Variability of per-capita water use with household size.

The next section describes the impact assessment of the four key variables used by this model which explain household water demand (Rathnayaka et al., 2015).

\section{Assessing the impact of demographic and structural changes on urban residential water use}

The spatial variability of demographic factors such as household size and presence of children and structural variables such as dwelling type and appliance efficiency is significant. To assess the significance and sensitivity of these variables, these variables are subjected to perturbations within the range of variation commensurate with those used in the model development.

\subsection{Household size}

The analysis reveals that per-capita water use decreases with increasing household size at a decreasing rate while per-capita water use for a person living alone is $60 \%$ higher than for a person living with a family of six members (Fig. 7). 


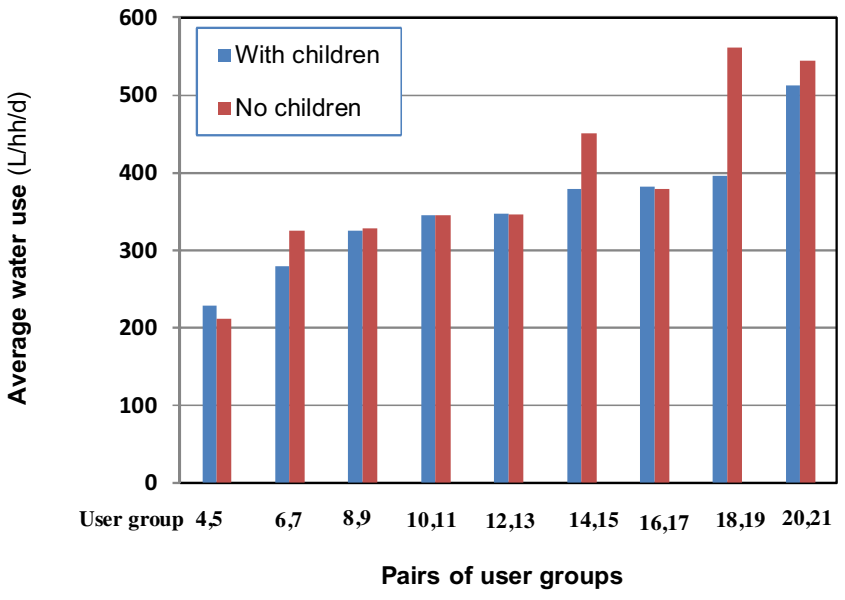

Fig. 8. Effect of presence of children on household water use.

This suggests that in an area where dwellings with lower occupancy are significant, this could lead to a significantly higher water use than the same population distributed in larger household sizes. This highlights the importance of considering the distribution of household size and their differences in water use in predicting residential water demand rather than per-capita water use which assumes per-person water use of all household sizes are same.

\subsection{Presence of children}

To determine the effect of presence of children under 12 years of age on household water use, the annual average water use of households with and without children for user groups of similar household sizes and dwelling types must be compared. User groups of household size 1 (i.e. user group 1, 2 and 3), and user group 22 which are a combination of households with and without children are excluded from this analysis.

As illustrated in Fig. 8, four out of nine pairs show that households with children under 12 years of age consume significantly less water than those households with no children. On average, the perperson water use of households without children is about $10 \mathrm{~L} / \mathrm{p} / \mathrm{d}$ higher than households with children, especially the shower water use.

\subsection{Appliance efficiency}

The analysis of shower type shows that on average efficient showers use $20 \%$ less water than standard showers, and dual flush toilets are $40 \%$ more efficient than single flush toilets. Front loader clothes washers show $50 \%$ greater efficiency than top loaders. Altogether, these efficient appliances save on average $35 \mathrm{~L} / \mathrm{p} / \mathrm{d}$.

\subsection{Dwelling type}

The analysis per capita water use in semi-detached dwellings shows that their water use is $19 \mathrm{~L} / \mathrm{p} / \mathrm{d}(13 \%)$ greater than multistorey dwellings, and $21 \mathrm{~L} / \mathrm{p} / \mathrm{d}(13 \%)$ lower than for detached dwellings. These differences can be principally attributed to the differences in presence of garden, evaporative cooler and pool between these dwelling types.

\section{Conclusions}

Prediction of urban residential water demand by considering variables that are significant over multiple spatial and temporal scales is challenging but necessary in urban water resource management and planning, in particular for the planning of decentralized systems. This paper presents an urban residential end-use water demand model with such capabilities.

The model consists of two key components: user groups and unique end-use models. User groups link key statistically significant variables: household size, typology of dwelling, the presence of children under 12 years of age, presence of water use appliances/end-uses and appliance efficiency into a single model. Data analysis showed that penetration rates of water end-uses (e.g. presence of garden, evaporative cooler, dishwasher) and water efficient appliances (e.g. efficient showers, front loader washing machines) vary significantly between different user groups. The key model features include:

- Unique end-use models for each user group provide an improved representation of variability in user behavior which is spatially lumped in existing end-use models.

- Predictor variables are represented by stochastic probability distributions instead of average values to describe the variability within a user group.

- Individual daily household data is used rather than average data to improve the representation of the variability of urban residential water use.

The impact assessment of structural and demographic factors on urban residential water demand shows the importance of considering the spatial and temporal variability of these variables in predicting urban residential water demand. While household size shows the greatest impact on urban residential water demand, the presence of children shows the least significance among all the variables. The ability to model households based on household size, dwelling type and presence of children improves model's accuracy over the approach based on spatially averaged models and, in addition, enables modeling at variable spatial scales. The model can also be used to predict peak water demand. These capabilities of the model make it a valuable tool to perform scenario analysis which is particularly important in IUWM planning.

\section{Acknowledgements}

Australian government (Research Training Scheme) and Australian Postgraduate Award are acknowledged for their financial contribution in this research. We would like to thank Yarra Valley Water and City West Water for providing their valuable data sets for this study. Special thanks to Mr. Peter Roberts from Yarra Valley Water for his valuable guidance and support for this research.

\section{Appendix A. Supplementary data}

Supplementary data associated with this article can be found, in the online version, at http://dx.doi.org/10.1016/j.resconrec.2016. 11.014 .

\section{References}

Athuraliya, A., Roberts, P., Brown, A., 2012. Residential Water Use Study, Volume 2-summer 2012. Yarra Valley Water, Melbourne.

Australian Bureau of Statistics, 2006. Population and Housing, Census of Melbourne (Statistical Division) VIC, Cat. No 2068.0. Australian Bureau of Statistics, Melbourne.

Baumann, D.D., Boland, J.J., Hanemann, W.M., 1998. Urban Water Demand Management and Planning. McGraw-Hill Inc., United States of America.

Bureau of Meteorology, 2011. Climate Data Online, Bureau of Meteorology. Australian Government (Available http://www.bom.gov.au/climate/data/ [Accessed 2011-14]).

Clark, R., Cresswell, D., 2007. Watercress User Manual (Available from: http:// www.waterselect.com.au/watercress/watercress.html [Accessed 10.11.2010]).

Department of Planning, Community Development, 2011. Suburbs in Time, Time Series Data on Demographics, Housing \& Population, Census Data from 1981 to 
2006 for Melbourne and Regional Suburbs. Viewed 5th May, 2013. <http:// www.dpcd.vic.gov.au/home/publications-and-research/urban-and-regionalresearch/metropolitan/suburbs-in-time>.

Domene, E., Sauri, D., 2006. Urbanization and water consumption: influencing factors in the metropolitan region of Barcelona. J. Urban Stud. 43 (9), 1605-1623, http://dx.doi.org/10.1080/00420980600749969.

Dugge, J., Pedrucob, P., Hardya, M.J., 2012. A Nearest-Neighbour Surrogate Model for the Simulation of Rainwater Tanks. 2012 International Congress on Environmental Modeling and Software-Managing Resources of a Limited Planet. Sixth Biennial Meeting, Leipzig, Germany, Available from http://www. iemss.org/society/index.php/iemss-2012-proceedings.

Galán, J.M., López-Paredes, A., del Olmo, R., 2009. An agent-based model for domestic water management in Valladolid metropolitan area. Water Resour. Res. 45, W05401, http://dx.doi.org/10.1029/2007WR006536.

Haddeland, I., Heinke, J., Biemans, H., Eisner, S., Flörke, M., Hanasaki, N., et al., 2014 Global water resources affected by human interventions and climate change. Proc. Natl. Acad. Sci. U. S. A. 111 (9), 3251-3256 (Available from: http://www. pnas.org/content/111/9/3251.full.pdf [Accessed 27.03.14.])

House-Peters, L.A., Chang, H., 2011. Urban water demand modeling: review of concepts, methods, and organizing principles. Water Resour. Res. 47, W05401, http://dx.doi.org/10.1029/2010WR009624.

House-Peters, L., Pratt, B., Chang, H., 2010. Effects of urban spatial structure, socio-demographics and climate on residential water consumption in Hillsboro, Oregon. J. Am. Water Resour. Assoc. 46 (3), 461-472, http://dx.doi. org/10.1111/j.1752-1688.2009.00415.x.

Kenney, D.S., Goemans, C., Klein, R., Lowrey, J., Reidy, K., 2008. Residential water demand management: lessons from Aurora, Colorado. J. Am. Water Resour. Assoc. 44 (1), 192-207, http://dx.doi.org/10.1111/j.1752-1688.2007.00147.x.

Lee, D., Park, N., Jeong, W., 2012. End-use analysis of household water by metering: the case study in Korea. Water Environ. J. 26 (4), 455-464, http://dx.doi.org/10. 1111/j.1747-6593.2011.00304.x.

Liu, A., Giurco, D., Mukheibir, P., 2015. Motivating metrics for household water-use feedback. Resour. Conserv. Recycl. 103 (2015), 29-46, http://dx.doi.org/10. 1016/j.resconrec.2015.05.008.

Maheepala, S., Blackmore, J., Diaper, C., Moglia, M., Sharma, A., Kenway, S., 2010. Integrated Urban Water Management Planning Manual Commonwealth Scientific Industrial and Research Organization (CSIRO). CSIRO publishing, Australia.

Maheepala, S., Coultas, E.H., Neumann, L.E., Beal, C.D., Stewart, R., Chong, M.N. Sharma, A.K., 2012. Quantifying potable water savings of rainwater tanks in South East Queensland by considering the spatial variability of tank supplies. In: The 3rd IWA-RWHM Conference and Exhibition, Goseong, Korea, 20-24 May, p. 2012.

Makki, A.A., Stewart, R.A., Beal, C.D., Panuwatwanich, K., 2015. Novel bottom-up urban water demand forecasting model: revealing the determinants, drivers and predictors of residential indoor end-use consumption. Resour. Conserv. Recycl. 95, 15-37, http://dx.doi.org/10.1016/j.resconrec.2014.11.009.
Mirza, F., Maheepala, S., Ashbolt, S., Neumann, L., Kinsman, D., Coultas, E., 2013. HydroPlanner: A Prototype Modeling Tool to Aid Development of Integrated Urban Water Management Strategies. Urban Water Security Research Alliance, Technical Report. P-6 (Available from: http://www.urbanwateralliance.org.au/ publications/UWSRA-tr108.pdf [Accessed 12.08.11.]).

Mitchell, V.G., Mein, R.G., McMahon, T.A., 2001. Modeling the urban water cycle. Environ. Model. Softw. 16 (97), 615-629, http://dx.doi.org/10.1016/S13648152(01)00029-9.

Mitchell, V.G., Duncan, H., Inman, M., Rahilly, M., Stewart, J., Vieritz, A., Holt, P., Grant, A., Fletcher, T.D., Coleman, J., Maheepala, S., Sharma, A., Deletic, A., Breen, P., 2007. State of the art review of integrated urban water models. In: Novatech 6th International Conference on Sustainable Techniques and Strategies in Urban Water Management, Lyon, France, 2007.

Rathnayaka, K., Malano, H., Maheepala, S., Nawarathna, B., George, B., Arora, M., 2011. Review of residential urban water end-use modeling. In: 19th International Congress on Modeling and Simulation, Perth Australia, 12-16 December 2011.

Rathnayaka, K., Maheepala, S., Nawarathna, B., George, B., Malano, H., Arora, M., Roberts, P., 2014. Factors affecting the variability of household water use in Melbourne, Australia. Resour. Conserv. Recycl. 92 (2014), 85-94, http://dx.doi. org/10.1016/j.resconrec.2014.08.012.

Rathnayaka, K., Malano, H., Maheepala, S., George, B., Nawarathna, B., Arora, M., Roberts, P., 2015. Seasonal demand dynamics of residential water end-Uses. Water 2015 (7), 202-216, http://dx.doi.org/10.3390/w7010202.

Rathnayaka, K., Malano, H., Arora, M., George, B., Maheepala, S., Nawarathna, B. (forthcoming). A Stochastic Model to Predict Urban Residential End-Use Water Demands at Multiple Scales to Aid Integrated Urban Water Management and Planning II: Model model Application and Validation.

Roberts, P., Athuraliya, A., Brown, A., 2011. Residential Water Use Study Volume 1-winter 2010. Yarra Valley Water, Melbourne, Australia.

Roberts, P., 2005a. Evaporative Air Conditioner Study. Yarra Valley Water, Melbourne, Australia.

Roberts, P., 2005b. Yarra Valley Water 2004-Residential End Use Measurement Study. Yarra Valley Water, Melbourne, Australia.

Roberts, P., 2012. 2011 Appliance Stock and Usage Pattern Survey. Yarra Valley Water, Melbourne, Australia.

Willis, R., Stewart, R.A., Panuwatwanich, K., Capati, B., Giurco, D., 2009. Gold Coast domestic water end-use study. J. Aust. Water Assoc. 36 (6), 79-85.

Yap, B.W., Sim, C.H., 2011. Comparisons of various types of normality tests. J. Stat. Comput. Simul. 81 (12), 2141-2155, http://dx.doi.org/10.1080/00949655.2010. 520163. 